\title{
COMMENTARY: QUANTITATIVE TIGHTENING: PROTECTING MONETARY POLICY FROM FISCAL ENCROACHMENT
}

\author{
William A. Allen*, Jagjit S. Chadha and Philip Turner \\ National Institute for Economic and Social Research, London, United Kingdom \\ ${ }^{\star}$ Corresponding author. Email: bill@allen-economics.com
}

\section{Overview}

As we face up to the need to plan an eventual exit from quantitative easing (QE), in this Commentary we consider how to reform both sides of the central bank balance sheet in a manner that will prepare the ground for a contraction in the balance sheet that does not expose the central bank to excessive risk. PostQE central bank balance sheets have a maturity mismatch, with long-term bonds as assets financed by liabilities in the form of commercial bank reserves bearing floating interest rates. In a central bank balance sheet contraction-quantitative tightening - the private sector will be asked to absorb those assets, which may place abrupt upward pressure on the yield curve. If policy interest rates rise, the interest cost of the central bank's liabilities will rise quickly while the interest income from its assets rises only slowly. Prompt and timely moves to reduce the mismatch by reducing the duration of assets and increasing that of liabilities will limit both the financial risks to the central bank and the risk of disruption to bond markets.

\section{Background}

Since the global financial crisis and the Covid pandemic, monetary, regulatory and fiscal policies have deepened the interconnections between the balance sheets of the central bank, the commercial banks and the government. QE, in which central banks buy long-term government bonds (to lower longterm interest rates), has created increased commercial bank reserve balances with the central bank. In addition, liquidity rules introduced after the global financial crisis have required commercial banks to increase their liquid asset holdings, including both reserve balances with the central bank and government securities.

COVID-19 induced governments to issue much more debt and led central banks into further QE. Monetary and fiscal policies have therefore become yet more entangled as central bank balance sheets have expanded once again (figure 1).

This paper argues that these developments threaten central bank independence and budgetary sustainability, and suggests how the threats might be mitigated. It also discusses how monetary policy might be tightened when the Monetary Policy Committee considers it appropriate to do so.

\section{Threats to central bank independence and budgetary sustainability}

Monetary policy now has large fiscal implications. When, for example, central banks begin to tighten monetary policy and raise rates (or when international long-term interest rates increase), there will be substantive implications for fiscal sustainability (Allen, 2021; Chadha et al., 2021; Landau, 2020). In the UK, the Office for Budget Responsibility (2021a) has underlined that even a modest rise in Bank rate with

(C) The Author(s), 2021. Published by Cambridge University Press on behalf of National Institute of Economic and Social Research. 


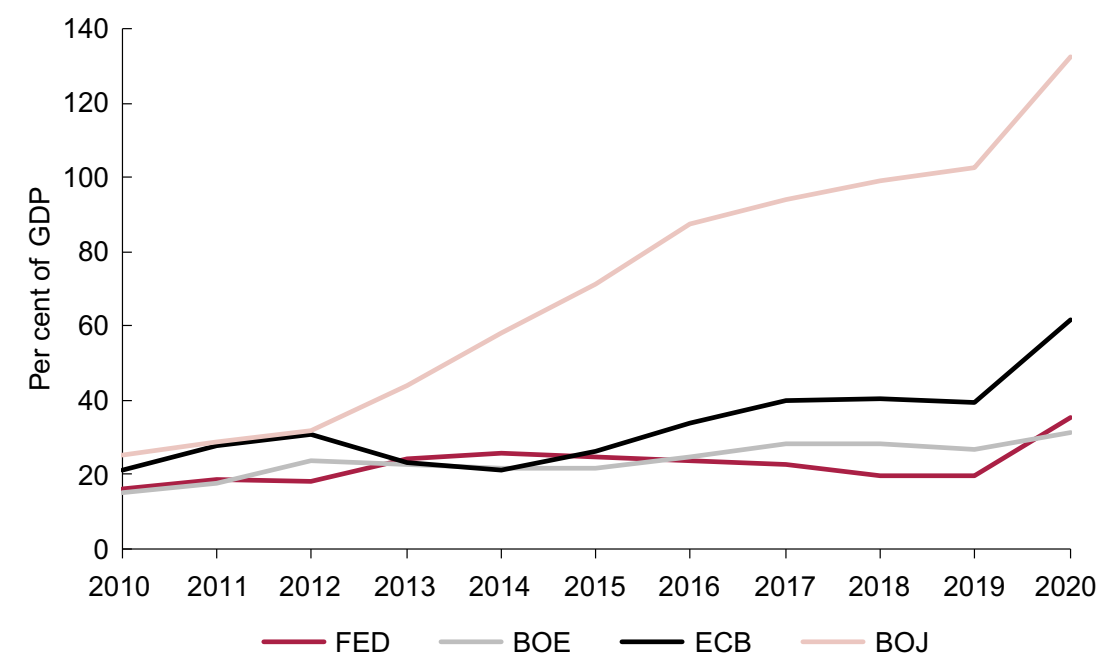

Figure 1. (Colour online) Major central bank balance sheets 2010-2020

parallel moves along the yield curve might make it harder to stabilise the government debt-to-GDP ratio. ${ }^{1}$ Given the uncertainty about future levels of interest rates, long as well as short, it is essential that the medium-term fiscal plans of governments be examined under alternative interest rate scenarios. In the UK, the independent Office for Budget Responsibility has carried out such an examination (2021b), and has identified plausible scenarios in which the public finances become unsustainable.

In this environment, there is an obvious risk of central banks being put under pressure to keep interest rates low in order to keep the government's debt servicing costs down. In other words, there is an unusually serious threat to central bank independence. Even the appearance that independence has been compromised would be dangerous.

Because of the interconnections among policy instruments, the transition to higher interest rates would be especially difficult. Achieving the transition while maintaining the independence of the central bank is crucial. ${ }^{2}$ A new debate on possible modalities is beginning.

\section{Reducing the interdependence of central banks and Treasuries}

The central bank and the Treasury should consider how adjustments in their respective balance sheets could reduce the risk that fiscal considerations might inhibit a future tightening of monetary policy. Once macroeconomic conditions improve and a tighter monetary policy is needed, uncertainty about future bond yields will increase. Central banks will not be able to sell their large holdings of government bonds as quickly as they bought them, or as quickly as they might want to, for fear of damaging the structure of bond markets. ${ }^{3}$ The risk of disruption is more serious for long-dated than short-dated bonds, because long-dated markets are typically less liquid.

We believe that, once we enter the exit phase, these sales would be better managed by the Treasury. It is the Treasury, not the central bank that is responsible for the domestic policies which fundamentally affect bond markets-that is, the medium-term fiscal framework and the sequence of current and

\footnotetext{
${ }^{1}$ The key point is that an interest rate 1 percentage point higher than in the Office for Budget Responsibility's forecast would increase debt interest spending by 0.8 per cent of GDP in fiscal year 2025/2026- 'two-thirds of the medium-term fiscal tightening announced by the Chancellor in his Budget' (Office for Budget Responsibility, 2021a).

${ }^{2}$ See, in particular, the evidence provided to the Select Committee on Economic Affairs of the House of Lords (2021). See also Chadha et al. (2021) and Landau (2020).

${ }^{3}$ For historical evidence of the influence of bond market structure on the scope for selling government debt, see Allen (2019).
} 
expected government budget decisions. Moreover, it is responsible for the programme of bond sales which finances budget deficits and the redemption of maturing debt.

Our proposal aims to limit even the appearance of conflicts between the Treasury and the central bank when macroeconomic policies have to tighten. In this part of the paper, we do not discuss changing the monetary/fiscal policy mix in any way. But our proposals would clear the decks for a future policy tightening by providing the Bank of England with securities that would be easier to sell than some of those which it has bought. That would make it easier to conduct monetary policy, and it would mean that monetary policy actions were less consequential for fiscal policy. The roles of monetary and fiscal policy would be disentangled, so that each could be managed separately in pursuit of its own objective (analogous to the analysis of Mundell, 1962).

\section{The central bank balance sheet}

Our proposal has two parts, one for the asset side of the central bank balance sheet and the other for the liability side.

\section{Central bank assets}

Our proposal is for the central bank and the Treasury to make the asset side of the central bank's balance sheet more liquid by conducting a swap of securities with the Treasury. The central bank would exchange with the Treasury all or part of its portfolio of long-term government bonds acquired under QE for a newly created portfolio of shorter maturity bonds (short-term bills or short-medium-term bonds). This would reduce the present huge maturity mismatch (long-term assets with very short-term liabilities) on the central bank's balance sheet.

The transaction would be wholly within the public sector, so that the consolidated balance sheet position of the public sector vis-à-vis the outside world would not change. The central bank would continue to roll over its holdings of government debt and banks' reserve balances would remain unaltered. Hence the monetary stimulation provided by QE would remain in effect until macroeconomic conditions dictated otherwise. The Bank of England's Monetary Policy Committee would continue to determine the quantity of the Bank's bond holdings in order to influence monetary conditions. The Treasury would find that the reported average remaining maturity of outstanding government bonds had declined. ${ }^{4}$ The illusion about the average maturity of government debt that has been created by the central bank transforming long-term government debt into short-term liabilities would to some significant extent be dispelled.

The proposal involves the transfer of interest rate risk from the central bank to the Treasury. That would make no real difference in the UK case because the Treasury has indemnified the Bank of England against losses on bond purchases under its QE measures, and has received the benefit of profits. Thus far, the programme has been very profitable for the Treasury, but it is very risky. The UK's Asset Purchase Facility, the account in which the bonds are held, has so far yielded $£ 112$ billion to the Treasury. Paying the banks for the reserves created by QE has so far proved to be much cheaper than paying bond holders. The reverse would however apply if and when interest rates rose above the levels implied by current bond yields. A parallel rise in the yield curve of a single basis point (a hundredth of a percentage point) would reduce the market value of the Bank's gilt portfolio by about $£ 1$ billion. ${ }^{5}$

If the proposed transaction were not done, and bond yields rose more sharply than current bond market prices suggest, how might politicians and the public react to the losses that would be recorded by the Bank of England? One can imagine accusations about the central bank being bailed out by the

\footnotetext{
${ }^{4} \mathrm{We}$ do not consider accounting issues. The convention that the national debt is reported with bonds valued at their face or redemption value means that a swap of Treasury bill (valued at market prices) for long-term bonds would affect the reported size of the national debt.

${ }^{5}$ Authors' calculation. The sensitivity of the market value to a given change in yields would decrease as yields rose (convexity).
} 
government and accompanying damage to central bank credibility. Moreover, the terms of the indemnity have not been published, for reasons that are not clear. ${ }^{6}$

Having only one official body responsible for selling bonds would be simpler and more efficient than having two official sellers who would in any case have to coordinate. One obvious method of co-ordination would be for the central bank to avoid active sales but not to reinvest the proceeds of maturing bonds. That would not, however, be a good solution. It would mean that the pace of contraction in the central bank's balance sheet would be determined by the redemption profile of past purchasesand independent of prevailing economic circumstances. It would also, in the UK, be very slow: the halflife of the Bank of England's bond portfolio is over 7 years.

The macroeconomic logic should be that sales will be larger when monetary restraint is required and slower when the economy weakens. If used in this manner, quantitative tightening - the opposite of QE-could become a useful monetary policy tool.

This proposal would in no way impair the independence of the central bank. It would not limit its ability to decide on operations in government bond markets if needed for monetary policy purposes. Such operations used in an expansionary direction were effective in 2009-2012. Long-term interest rates were reduced by QE, with significant macroeconomic and financial stability benefits at a difficult time (Gagnon, 2016; Turner, 2021a). More recently, the prompt and substantial response of monetary policy to the coronavirus pandemic was a vital complement to expansionary fiscal policy in limiting output and employment losses (Chadha et al., 2021). But it would be impossible for central banks to sell government bonds of similarly long average maturity at a similar pace when restrictive monetary policy was required. If the maturity of the central bank's bond portfolio were to be shortened, as we have suggested, the central bank would have more flexibility in tightening policy. If it wanted to sell bonds to tighten policy, it would transfer bonds from its portfolio to the Treasury in exchange for Treasury bills, and ask the Treasury to sell them in the market over a certain period. The central bank could choose whether to retain the Treasury bills, rolling them over on maturity or allow them to run off (or sell them) and have the commercial banks' reserve balances fall back in parallel.

\section{Government debt management}

The Treasury (or its debt management agency) would continue to manage the maturity of new bond issuance. It would have to manage refunding risks. And it would, as always, be responsible for choosing between shorter-term borrowing at a lower interest rate and longer-term borrowing at a higher rate as an insurance against future increases in interest rates in the exit phase from QE. The choice of debt instrument (e.g. nominal, inflation-linked or GDP-linked bonds) is also a matter for the Treasury (Chadha, 2021). The authorities would also have to weigh whether shorter debt maturities could encourage more prudent fiscal policy by reducing the fiscal windfall that an unexpected rise in inflation would bring (Broadbent, 2020).

\section{Central bank liabilities}

Most central bank liabilities are the assets of private financial institutions. The main central bank liability created by QE has been bank reserves-very short-term deposits of commercial banks which have since 2009 been remunerated at Bank Rate.

\footnotetext{
${ }^{6}$ The House of Lords Economic Affairs Committee (2021) argues on p. 47 that ' $\mathrm{t}$ ] he asset purchase facility is indemnified by HM Treasury, but the Deed of Indemnity has not been published. This is a contractual document between two public institutions. We heard no convincing explanation for why the document has not been placed in the public domain, which has concealed it from parliamentary and public scrutiny. The Chancellor has repeatedly ignored our requests for an explanation on why the document has not been published. HM Treasury should publish the Deed of Indemnity'.
} 
Currently reserves at the Bank of England are about $£ 800$ billion (36 per cent of GDP), and are still rising. The interest-paying liabilities of the Fed are about $\$ 4.5$ trillion (20 per cent of GDP). ${ }^{7}$ As already noted, such large reserves have made central bank payments to banks more sensitive to changes in the policy rate.

\section{End the remuneration of reserves?}

Whatever the economic arguments, large payments to banks may be hard to swallow politically, adding an unwelcome twist to the monetary and fiscal policy entanglement. One expedient to deal with a weak fiscal position would be to break one of the linkages from monetary policy to government finance by ending (or at least drastically curtailing) the practice of remunerating reserves (Holtham, 2021), or by tiering reserves so that only some fraction will be so remunerated (Goodhart, 2021). ${ }^{8}$ Such ideas merit careful consideration.

International practices on the remuneration of bank reserves vary, and indeed change over time. Some central banks will not remunerate (or charge for if the policy rate is negative) an infra-marginal proportion of reserves. In addition, central banks can also vary the size of required reserves if they want to prevent excess liquidity inducing increased bank lending-a potent tool of monetary policy in bank-dominated financial system. But central banks in the advanced economies have not used this as a significant monetary policy tool in recent years, in part because they did not want to put banks at a disadvantage to capital markets.

There are three doubts, however, about the wisdom of such an expedient in the current environment.

The first is that it would be a 'windfall' tax on the banking system which would grow as interest rates rose. Remember that it was regulation which forced banks to hold more liquid assets-and most regulators see reserves with the central bank as the best liquid asset. Such a tax would lead to disintermediation of financial flows away from banks into less visible and less secure channels. The migration of international credit away from banks to capital markets since the global financial crisis has already created new and opaque risks for financial stability. The Financial Stability Board is currently considering how to plug the regulatory gaps in non-bank financial intermediation notably in mutual funds and bond markets (Quarles, 2021). The tax would also make it even harder than it currently is for banks to raise capital from investors when needed. And the tax would be justified by nothing more than expediency: it would create the impression that anybody unfortunate enough to have lent money to the government, even involuntarily, is in danger of a form of expropriation.

The second doubt concerns how banks would react: their portfolio adjustments would affect market interest rates. Making reserves non-interest-bearing just when the policy rate is being increased and the banks have suffered capital losses on their longer-term government bonds would force banks to reassess their whole portfolio of liquid assets. The initial effect would be that individual banks would seek to replace some reserves with short-term government bonds, and perhaps sell longer-term government bonds to keep the average duration of their liquid assets constant in their portfolio. The structure of interest rates would adjust, and that would amount to an unplanned change in monetary policy.

The third reason is that the normal implementation of monetary policy would be disabled. At present, the main interest rate instrument used by central banks is precisely the interest rate paid on reserves. It is true that some central banks have operated arrangements which keep the rate on marginal reserve balances at the policy rate (so maintaining monetary policy traction) but have a zero-interest rate on other reserves. Introducing new minimum reserve requirements to cover the non-interest-bearing part of the reserves would mean that such reserves could not be used to cover liquidity gaps, and would

\footnotetext{
${ }^{7}$ Nelson (2021).

${ }^{8}$ Limiting interest payments for reserves would not work in the euro area; see Papadopoulos (2021) on how the risk of any fiscal policy trap for the ECB might be reduced.
} 
therefore not be a true liquid asset. And, as noted already, it would drive financial intermediation into other channels.

\section{The role of bank regulation}

The role of new regulations introduced after the financial crisis has been key. Under Basel III, banks have had to hold much larger stocks of high-quality liquid assets, which include not only bank reserves but also government bonds. This decision to count long-term bonds-and not just short-term paper-as a liquid asset helps governments finance their deficits more easily. In addition, the Basel Committee on Banking Supervision has repeatedly tried and failed to agree a Pillar 1 capital charge on interest rate risk. Once again, this has been a boon to governments-especially those which are heavily indebted.

The consequence of these regulatory shortcomings and a decade of very low long-term interest rates is that banks face large interest rate risk exposures. ${ }^{9}$ Moreover such exposures are opaque and very uncertain. Opaque because the scale of hedging in derivatives markets is unknown: many banks will have swapped fixed-rate bonds for floating. Uncertain because banks will seek profits by accepting interest rate exposures when markets are calm, hedging only when they deem necessary. But hedging markets are often not resilient in times of stress. Several recent episodes of severe disruption in supposedly what are usually very liquid interest rate markets hint at the scale of the problem. When interest rate expectations change, banks and others will seek to reduce their interest rate exposures in benchmark government bond markets or cover them in interest rate derivative markets. If central banks become more reluctant to intervene on a large scale, market liquidity could evaporate. The latent vulnerabilities of banks might then be revealed.

Over several years, the capacity of dealers in bond markets to maintain liquid two-way markets in government securities has been reduced. The Basel III leverage ratio bears particularly hard on holdings of large-volume low-risk assets. In our view, commercial banks should not face capital charges for their deposits with the central bank or for their holdings of short duration government bonds: such assets should therefore be excluded from the leverage ratio.

A clear warning about the capacity of bond markets came in March 2020 when an avalanche of sales of bonds proved too much for the market makers to absorb. Faced with severe market disorder, the Fed and other central banks were forced to act as market makers of last resort (Hauser, 2021). Countering this failure of market liquidity as much as monetary policy easing per se was a key motivation for the recent massive extension of QE (that of the $\mathrm{UK}$, for instance, will have doubled when the current programme is complete).

\section{The transition to higher interest rates}

This section goes beyond the analysis of previous sections by discussing how a tightening of policy might be accomplished when the time comes.

Because of the large increase in bond debt relative to GDP over the past decade, the macroeconomic consequences of changes in long-term interest rates are likely to have increased. By May 2021, it seemed that the combination of strong private sector borrowing and the steep rise in government borrowing had begun to lift long-term interest rates in world markets despite continued central bank bond purchases. This was especially evident in the global benchmark of US Treasuries. More recently, however, bond yields have fallen back.

Nevertheless, for the first time in 25 years, inflation risks have caught the attention of investors. Household savings, accumulated during the pandemic when budget deficits were large and opportunities to spend were constrained, can be expected to be run down. If a structural shift of saving-investment balances in the direction of global saving shortage has increased $\mathrm{r}^{\star}$ (the natural or equilibrium real short-

\footnotetext{
${ }^{9}$ See chapter 7 of Turner (2021a) for a summary of recent studies on the scale of interest risk in banks and other financial institutions. Central bank simulations suggest that it is the banks that are likely to be hardest hit by a sharp and unexpected increase in interest rates.
} 
term interest rate), central banks would have to raise the policy rate more than the market currently expects in order to contain inflation (Turner, 2021b). Bond yields could then rise suddenly. The vulnerability of the central bank's balance sheet (and thus government finances) to lower bond prices and higher policy interest rate is therefore now greater than at any time during the QE decade.

There is no magic solution to such an interest rate transition. But when the time comes to tighten policy, steps could be taken to limit the risk of sudden shocks to the liability side of the central bank's balance sheet. If our proposal were implemented, the central bank would, as noted above, have swapped with the Treasury some long-term bonds for short-term government paper.

Rather than ending or curtailing the payment of interest on reserves, we would prefer to convert some proportion of banks' reserves into shorter maturity government bonds (Allen, 2021). The conversion would have to be compulsory, since an auction of a very large amount of bonds would certainly be undersubscribed. Such a measure could be made more palatable for the banks by exempting short duration government bonds from the leverage ratio. How much to convert would depend on an assessment of the structural demand for reserves, which has greatly increased since the global financial crisis. At current yields, the interest cost to the government would be low. This policy would transfer some interest rate risk to the banks. Regulatory stress tests on banks for a sharp rise in bond yields would be needed.

The conversion would replace a bank asset of zero maturity with assets of, say, 2-year average maturity (McCauley, 2021 makes a similar proposal). The banks would therefore have to sell or hedge some bonds if they wanted to keep the duration of their interest rate exposures constant. Yields on government bonds would rise. A modest first step could test the size of such an impact.

After the operation had been conducted, the maturity structure of government debt held in the market, and hence the interest rate risk exposure of the government, might not be what the Treasury wanted. It would be open to the Treasury to adjust the maturity structure over time as it saw fit.

The present macroeconomic situation has some important features in common with that which prevailed in the UK at the end of the Second World War: specifically large amounts of liquid savings, the release of pent-up demand and very low interest rates. The proposed conversion of commercial banks' reserve balances into short and medium dated bonds is very similar to the one undertaken in November 1951 to convert some of the commercial banks' large holdings of Treasury bills, built up during the war, into short-dated bonds, as a means of restricting demand. ${ }^{10}$

Government debt/GDP ratios have risen sharply. Major central banks maintain substantial purchases of government bonds. Higher interest rates will inevitably have large effects on the balance sheets of the central bank, the government and the commercial banks. There is a strong case for considering balance sheet adjustment now when interest rates are still low. This is why the current debate on this issue is important. ${ }^{11}$ In order to protect the independence of the central bank there is a case for alternative arrangements which better clarify the separation between monetary policy and fiscal policy. Cautious but early action is the order of the day.

Acknowledgements. We thank Richard Barwell, Brandon Davies, Charles Goodhart, Rosa Lastra, Rory Macqueen, Chris Marsh, David Miles, Richhild Moessner, Paul Mortimer-Lee, Barry Naisbitt, Bill Nelson, Paul Tucker and Tim Young for helpful comments and discussions. Any errors are ours alone. This policy paper is issued to promote debate.

\section{References}

Allen, W.A. (2014), Monetary Policy and Financial Repression in Britain, 1951-1959, Basingstoke: Palgrave Macmillan.

Allen, W.A. (2019), The Bank of England and the Government Debt: Operations in the Gilt-edged Market 1928-1972, Cambridge: Cambridge University Press.

Allen, W.A. (2021), 'Managing the fiscal risk of higher interest rates', NIESR policy paper 25, 26 March 2021.

\footnotetext{
${ }^{10}$ Allen (2014, pp. 21-31) and Howson (1993, pp. 310-5).

${ }^{11}$ The Bank of England has outlined plans for unwinding QE, possibly including outright sales of government bonds (Bank of England 2021, Box A).
} 
Bank of England (2021), Monetary Policy Report, August.

Broadbent, B. (2020), 'Government debt and inflation', Speech at the annual meeting of the Central Bank Research Association, 2 September.

Chadha, J.S. (2021), 'Fiscal policy, uncertainty and debt instruments' in Chadha, J.S., Küçük, H. and Pabst, A. (eds), Proposals for a New Fiscal Framework, London: NIESR Occasional Paper No. 61.

Chadha, J.S., Corrado, L., Meaning, J. and Schuler, T. (2021), 'Monetary and fiscal complementarity in the COVID-19 pandemic', CEPR Covid Economics, 81, p. 76.

Chadha, J.S., Küçük, H. and Pabst, A. (eds) (2021), Proposals for a New Fiscal Framework, NIESR occasional paper no. 61 , May.

Gagnon, J.E. (2016), 'Quantitative easing: An under-appreciated success', Petersen Institute for International Economics, Policy Brief PB16-4.

Goodhart, C.A.E. (2021), 'Letter: A simple solution to worrisome debt levels', Financial Times, 19 January.

Hauser, A. (2021), 'From Lender of Last Resort to Market Maker of Last Resort via the dash for cash: Why central banks need new tools for dealing with market dysfunction', Speech by Bank of England Executive Director.

Holtham, G. (2021), 'Monetary policy and the value of public debt', in Chadha, J.S., Küçük, H. and Pabst, A. (eds), Proposals for a New Fiscal Framework, London: NIESR Occasional Paper No. 61.

House of Lords (2021a), 'Evidence on quantitative easing provided to the Select Committee on Economic Affairs'.

House of Lords (2021b), 'Quantitative easing: A dangerous addiction?', Economic Affairs Committee 1st report of session 2021-22.

Howson, S.K. (1993), British Monetary Policy 1945-1951, Oxford: Oxford University Press.

Landau, J.-P. (2020), 'Money and debt: Paying for the crisis', Vox-EU CEPR, 23 June.

McCauley, R. (2021), 'Unstuffing banks with fed deposits: Why and how,' Vox-EU CEPR, 30 March 2021.

Mundell, R. (1962), 'The appropriate use of monetary and fiscal policy under fixed exchange rates', International Monetary Fund Staff Papers, 10, pp. 70-7.

Nelson, W. (2021), 'Big genie, small bottle: Normalising monetary policy', Bank Policy Institute, 12 May.

Office for Budget Responsibility (2021a), 'Economic and fiscal outlook - March 2021', available online at https://obr.uk/efo/ economic-and-fiscal-outlook-march-2021/.

Office for Budget Responsibility (2021b), 'Fiscal risks report', July, available online at https://obr.uk/frr/fiscal-risks-reportjuly-2021/.

Papadopoulos, C. (2021), 'Central banks need to escape fiscal policy and debt management trap', OMFIF, 10 May.

Quarles, R.K. (2021), 'The FSB in 2021: Addressing financial stability challenges in an age of interconnectedness, innovation, and change', Speech on 30 March 2021.

Turner, P. (2021a), 'A new monetary policy revolution', NIESR occasional paper no. 60, February.

Turner, P. (2021b), 'A latent rise in $\mathrm{r}^{\star}$ could upend monetary policy', Central Banking, 31 March.

Cite this article: Allen, W. A., Chadha, J. S. and Turner, P. (2021), 'Commentary: Quantitative tightening: Protecting monetary policy from fiscal encroachment', National Institute Economic Review, 257, pp. 1-8. https://doi.org/10.1017/ nie.2021.27 